\title{
The Hydration of Heavy Metal Salts Admixtured High Alumina Cement - A X-Ray Diffraction Study
}

\author{
R. Nithya \\ Department of Physics, Annamalai University \\ Annamalainagar 608 002, Tamilnadu, India \\ E-mail: nivelan_15@yahoo.com \\ S.Barathan (Corresponding author) \\ Department of Physics, Annamalai University \\ Annamalainagar 608 002, Tamilnadu, India \\ E-mail: sbarathan.au@rediffmail.com \\ M.Gopalakrishan \\ Department of Chemistry, Annamalai University \\ Annamalainagar 608 002, Tamilnadu, India \\ E-mail: profmgk@yahoo.co.in \\ G.Sivakumar \\ Department of Physics, Annamalai University \\ Annamalainagar 608 002, Tamilnadu, India \\ E-mail: gsk_cisl@yahoo.com \\ B.Gobinath \\ Department of Physics, Annamalai University \\ Annamalainagar 608 002, Tamilnadu, India \\ E-mail: gobinathb@yahoo.com
}

\begin{abstract}
The XRD, Setting time and Compressive strength results of the hydration of High Alumina Cement (HAC) with different concentrations of $\mathrm{Cr}, \mathrm{Cd}, \mathrm{Pb}, \mathrm{Zn}$ and $\mathrm{Mg}$ as impurities are presented. The heavy metal salts are doped from 100 to $15000 \mathrm{ppm}$ in various steps. The hydration products are investigated both qualitatively and quantitatively by X-ray powder diffraction. The initial, final setting time and strength of heavy metal salts doped HAC, which are measured and compared with the phases at different time intervals are discussed. The results show that various concentrations of heavy metal salts doped HAC can play an effective role in conversion reactions (i.e.) from metastable to stable hydrates imparting setting time and strength. It is observed that a lower concentration of industrial waste metal ions do not affect the characteristics of the blend.
\end{abstract}

Keywords: HAC, Heavy metal ions, XRD, Mechanical properties 


\section{Introduction}

The cost of High Alumina Cement (HAC) is higher than any Ordinary Portland Cement (OPC) due to its ingredients. Though its competeness with OPC in everyday application is almost nil, due to its higher strength it gives a helping hand when OPC's function and performanance are insufficient in certain applications. In general a parallel practical utility can be obtained by admixturing it with suitable metal ions in certain conditions.

The main difference between OPC and HAC lies in the nature of their active phases that lead to setting and hardening. HAC develops substantially higher strength than OPC. The high early strength characteristics of HAC take facility in emergency repair work due to its quick setting. Monocalcium aluminate (CA) is the principal active phase in HAC. When mixed with water, depending on the metal ion concentration available in water, the properties of the products vary. Chromium $(\mathrm{Cr})$, Lead $(\mathrm{Pb})$, Cadmium $(\mathrm{Cd})$, Zinc $(\mathrm{Zn})$ and Magnesium $(\mathrm{Mg})$ are the major metal ions that are dissolved in ground water either through industrial pollution or through environmental factors. On hydration, the effects of these metal ions by their product are noteworthy.

The hydration reaction of High Alumina Cement at environmental temperature produces metastable hexagonal hydrated calcium aluminates $\mathrm{CAH}_{10}\left(\mathrm{CaAl}_{2} \mathrm{O}_{14} \mathrm{H}_{2} \mathrm{O}\right)$ and $\mathrm{C}_{2} \mathrm{AH}_{8}\left(\mathrm{Ca}_{2} \mathrm{Al}_{2} \mathrm{O}_{13} \mathrm{H}_{16}\right)$. However the stable phases are $\mathrm{C}_{3} \mathrm{AH}_{6}$ $\left(\mathrm{Ca}_{3} \mathrm{Al}_{2}(\mathrm{OH})_{12}\right)$ and $\mathrm{AH}_{3}\left(\mathrm{Al}(\mathrm{OH})_{3}\right)$ and other phases inevitably gets converted to these (Ana Hidalgo et al., 2009).

The conversion reactions are shown schematically below

$$
\begin{array}{ll}
3 \mathrm{CAH}_{10} \rightarrow & \mathrm{C}_{3} \mathrm{AH}_{6}+2 \mathrm{AH}_{3}+18 \mathrm{H} \\
3 \mathrm{C}_{2} \mathrm{AH}_{8} \rightarrow(1) & \rightarrow \mathrm{C}_{3} \mathrm{AH}_{6}+\mathrm{AH}_{3}+9 \mathrm{H} \rightarrow(2)
\end{array}
$$

The aim of the present work is to study the hydration properties of HAC with heavy metal salts namely Cadmium Carbonate $\left(\mathrm{CdCO}_{3}\right)$, Zinc Sulphate $\left(\mathrm{ZnSO}_{4} \cdot 7 \mathrm{H}_{2} \mathrm{O}\right)$, Magnesium Sulphate $\left(\mathrm{MgSO}_{4} \cdot \mathrm{H}_{2} \mathrm{O}\right)$, Lead Nitrate $\left(\mathrm{Pb}\left(\mathrm{NO}_{3}\right)_{2}\right)$ and Potassium dichromate $\left(\mathrm{K}_{2} \mathrm{Cr}_{2} \mathrm{O}_{7}\right)$ which are major pollutants from Industries. The water soluble salts of the above metals are dissolved using groundwater in different concentrations from 100 to $15000 \mathrm{ppm}$ to study the effect on setting time and strength of the paste. The mechanical measurement has revealed that the concentration of $2000 \mathrm{ppm}$ is optimum. The XR diffractograms for the admixed paste were recorded at different time intervals of hydration and compared with mechanical measurements. This has been substantiated by workability, flowability and consistence measurements.

\section{Experimental Methods}

Commercially available HAC and heavy metal salts of higher purity (E-Merck) (Cd, Mg, $\mathrm{Pb}, \mathrm{Zn}$ and $\mathrm{Cr}$ ) are used. The heavy metal salts say $(2000 \mathrm{ppm})$ on a metal basis are first dissolved in one liter ground water whose water analysis have been carried out and made to a solution. This is added to HAC whose chemical composition is given in Table. 1 in a water/cementitious ratio of 0.4 , allowed to hydrate and dehydrated at different time intervals after proper curing, wherever necessary. This procedure is carried out with different metal ions in different concentrations $(100,500,1000$, $2000,3000,5000,10000$ and $15000 \mathrm{ppm}$ ) at a temperature of $30^{\circ} \mathrm{C}$, using the standard procedure adopted by various workers (Stephan, et al., 1999). The Consistency, Flowability and Workability were also measured using standard procedure.

The Initial Setting Time (IST) and Final Setting Time (FST) of the paste containing heavy metal salts are measured using Vicat's apparatus with a consistency sample as per Standard Procedure and are shown in non linear scale (Fig.1). The compressive strength of all the samples is measured after adopting, standard procedure and proper curing (Waldemar, et al., 2002). For the sake of convenience the $28^{\text {th }}$ day strength alone is presented and is shown in a non linear scale (Fig. 2). Though the XRD pattern for various hydrated time intervals are recorded, $28^{\text {th }}$ day strength is prominent for analysis, it is preferred for a concentration of 2000ppm and are shown in Fig.3.

The Quantitative estimation of these important phases were also carried out using the Rietveld method (Guirado, et al., 2000) and reported (Table. 2) for the $28^{\text {th }}$ day diffractogram only.

The XRD pattern of all the samples were recorded using PANalytical (Philip - Netherlands) at Pondicherry University, Pudhucherry with $\mathrm{CuK}_{\alpha}$ radiation $(\lambda=1.5460 \AA)$ at $40 \mathrm{kV}$ and $30 \mathrm{~mA}$. The patterns were recorded from $2 \theta=10$ to $60^{\circ}$ in the range $2^{\circ} / \mathrm{min}$. The intensities were calculated with the help of $X^{\prime}$ pert software available with the instrument.

\section{Results and Discussion}

A close scrutiny of the (Table.2) reveals that the change in weight percentage of the phases depending on time helps one to identify the reactions and its consequences.

A close scrutiny of the Fig. $1 \& 2$ suggests that 2000ppm of metal ions is an optimum concentration for both Setting time and Strength. For all the salt added pastes, depending on metal ions the variations in setting time can be arranged in the order $\mathrm{Cd}>\mathrm{Zn}>\mathrm{Pb}>\mathrm{Mg}>\mathrm{Cr}$. The observed compressive strength (Fig. 2) indicates that the addition of heavy 
metal salts does not alter the value very much except $\mathrm{Zn}$ added paste compared to HAC's value at this concentration of $2000 \mathrm{ppm}$.

The assignment of different X-ray peaks to the compounds in HAC (Fig.3) is fixed on the lines of Harchand et al. It is evidenced from hydrated HAC diffractograms that $\mathrm{C}_{12} \mathrm{~A}_{7}$ and $\mathrm{C}_{2} \mathrm{AS}$ go on reducing as time elapses and at one week, these phases are converted to $\mathrm{CA}$ (Harchand, et al., 1984). At 1 day, XRD reveals that $\mathrm{C}_{2} \mathrm{AH}_{8}$ is the main hydration product. There is some $\mathrm{CAH}_{10}$. No $\mathrm{C}_{3} \mathrm{AH}_{6}$ could be detected. After 7 days the phases of $\mathrm{CAH}_{10}, \mathrm{C}_{2} \mathrm{AH}_{8}$ and $\mathrm{C}_{3} \mathrm{AH}_{6}$ have appeared. The proportion of intensity has increased is higher in $\mathrm{C}_{2} \mathrm{AH}_{8}$. Various peaks trace of $\mathrm{C}_{3} \mathrm{AH}_{6}\left(2 \theta=44^{\circ}: \mathrm{d}=2.04\right.$ $\AA), \mathrm{CAH}_{10}\left(2 \theta=20^{\circ}: \mathrm{d}=4.36 \AA\right), \mathrm{AH}_{3}\left(2 \theta=31^{\circ}: \mathrm{d}=2.85 \AA\right)$ are present with variation in intensity at $28^{\text {th }}$ day spectra. The growth of the metastable phases $\mathrm{CAH}_{10}$ on $\mathrm{C}_{2} \mathrm{AH}_{8}$ in the later hydration periods is indicative of its slightly higher compressive strength. A trace of gibbsite is also noticed.

XRD spectrum of $\mathrm{Cd}$ added $\mathrm{HAC}$ paste shows a reduction in intensity of the phases $\mathrm{CAH}_{10}$ and $\mathrm{C}_{2} \mathrm{AH}_{8}$ in early hydrated diffractogram. This indicates an increase in early compressive strength. The increasing $\mathrm{C}_{3} \mathrm{AH}_{6}$ peak observed at $28^{\text {th }}$ day is indicative of reduction in strength. A close scrutiny of the spectra at different time intervals reveals that the presence of $\mathrm{Cd}$ delays the formation of $\mathrm{C}_{3} \mathrm{AH}_{6}$ phase (Murat and Sorrentino et al., 1996). This may retard the setting time but does not modify the strength very much. Additional calcium chloroaluminate and calcium alumino ferrite peaks are also detected (Sanjuan, et al., 1997).

A close scrutiny of the $\mathrm{Zn}$ added diffractograms and its quantative estimation of phases at different time frames reveal a non linear reduction of the phases of $\mathrm{C}_{2} \mathrm{AH}_{8}$ and $\mathrm{CAH}_{10}$ and non uniform increase of phases is noticed. This implies that the presence of $\mathrm{Zn}$ slightly accelerates the hydration reaction and the rate of formation of $\mathrm{C}_{3} \mathrm{AH}_{6}$ hydrate increases. This probably causes the setting time to decrease rapidly but the strength is found to be lower than control. Some additional peak of calcium chloroaluminates, ferrite and zinc aluminates are observed in hydrated $28^{\text {th }}$ day spectrum (Stephan, et al., 1999).

The mix with $\mathrm{Pb}$ addition in the $28^{\text {th }}$ day spectra shows, a reduction in intensity of the peak at $\mathrm{CAH}_{10}$ and an increase in the peak at $\mathrm{C}_{2} \mathrm{AH}_{8}$ and $\mathrm{C}_{3} \mathrm{AH}_{6}$. A close watch on the XRD patterns of $\mathrm{Pb}$ added paste and the quantitative estimation of the phases suggest that a normal and gradual change might have been occurred for the phase $\mathrm{CAH}_{10}$. In other words, $\mathrm{CAH}_{10}$ phases compensate the faster reaction of the other phase and have a setting time almost equal to that of control. On the other hand, an increase in intensity and hence the amount of these phases $\mathrm{C}_{2} \mathrm{AH}_{8}$ and $\mathrm{C}_{3} \mathrm{AH}_{6}$ increases. Comparing the amount of the phases with control, it is observed that the loss in strength created through $\mathrm{C}_{3} \mathrm{AH}_{6}$ is compensated by $\mathrm{C}_{2} \mathrm{AH}_{8}$ phases (Table 2). In addition peaks observed for calcium chloroaluminates and gehlenite at $28^{\text {th }}$ day is also compensated by $\mathrm{C}_{2} \mathrm{AH}_{8}$ phase thereby making the strength almost equal to control (Murat, et al., 1996).

The XRD patterns of $\mathrm{Cr}$ added HAC paste and its quantitative estimation of phases at various time intervals indicates that the $\mathrm{C}_{3} \mathrm{AH}_{6}$ phase is proceeding faster than $\mathrm{C}_{2} \mathrm{AH}_{8}$ and $\mathrm{CAH}_{10}$ phases. The increase in amount of $\mathrm{C}_{3} \mathrm{AH}_{6}$ and decrease in the amount of phases $\mathrm{C}_{2} \mathrm{AH}_{8}$ and $\mathrm{CAH}_{10}$ are indicative of delayed setting time and lower strength than the control. An increase in $\mathrm{Cr}$ concentrations in HAC indicates a reduction in strength than control (Minocha, et al., 2003).

The $28^{\text {th }}$ day diffractogram of the $\mathrm{Mg}$ mixed sample shows an increased intense peak for $\mathrm{C}_{3} \mathrm{AH}_{6}$ and decreased intense peak for $\mathrm{CAH}_{10}$. The observed variations are similar to that of other studied metal ions. The observed additional peaks were identified as $\mathrm{MgAl}_{2} \mathrm{O}_{4}$ (Prodjosantoso and Kennedy, 2003). The Observed flowability and workability supports all the results discussed above.

The final concentrations of various metals have been verified through quantitative chemical analysis and the final result is well within the experimental errors.

\section{Conclusion}

XRD is the most primary investigative technique in cement chemistry to identify and estimate the constituent phases. The qualitative and quantitative estimation of phases reveal that the addition $(2000 \mathrm{ppm})$ of heavy metal salts $(\mathrm{Cd}, \mathrm{Cr}$, $\mathrm{Pb}, \mathrm{Zn}$ and $\mathrm{Mg}$ ) to $\mathrm{HAC}$ is optimum at $30^{\circ} \mathrm{C}$. This produces cementitious mixture that does not alter very much from control compressive strength except $\mathrm{Zn}$. $\mathrm{Zn}$ has a deleterious effect on $\mathrm{HAC}$ compared to $\mathrm{Cr}, \mathrm{Pb}, \mathrm{Cd}$ and $\mathrm{Mg}$ and hence cannot be added even in small quantity. The effect of the addition of metal ions on compressive strength of HAC may be placed as $\mathrm{Cd}>\mathrm{Zn}>\mathrm{Pb}>\mathrm{Mg}>\mathrm{Cr}$.

\section{References}

Ana Hidalgo, J., Garcia, L., Cruz Alonso, M., Fernandez, L. \& Carmen Andrade. (2009). Microstructure development in mixes of calcium aluminate cement with silica fume or fly ash. Journal of Thermal Analysis and Calorimetry, 49(2), $1-10$.

Guirado, F., Gali, S., \& Chinchon, S. (2000). Quantative Rietveld analysis of aluminous cements clinker phases Cement and Concrete Research, 30, 1023-1029. 
Harchand, K.S., Vishwamitter., \& Chandra, K. (1984). A study of the iron phase and its hydration behavior in alumina cement. Cement and Concrete Research, 17, 19-24.

Minocha, A.K., Neeraj Jain, \& Verma, C.L. (2003). Effect of inorganic materials on the solidification of heavy metal sludge. Cement and Concrete Research, 33, 1695-1701.

Murat, M., \& Sorrentino, F. (1996). Effect of Large additions of Cd, Pb, Cr, Zn to raw meal on the composition and the propertities of the clinker and the cement. Cement and Concrete Research, 26(3), 377-385.

Prodjosantoso, A.K., \& Kennedy, B.J. (2003) Heavy metals in cement phases: on the solubility of $\mathrm{Mg}, \mathrm{Cd}, \mathrm{Pb}$ and $\mathrm{Ba}$ in $\mathrm{Ca}_{3} \mathrm{Al}_{2} \mathrm{O}_{6}$. Cement and Concrete Research, 33, 1077-1084.

Sanjuan, M.A. (1997). Formation of chloroaluminates in calcium aluminate cements cured at high temperatures and exposed to chloride solutions. Journal of Materials Science, 32, 6207-6213.

Stephan, D., Mallmann, R., Knofel, D., \& Hardtl, R. (1999). High intakes of Cr, Ni and Zn in Clinker Part II Influence on the hydration properties. Cement and Concrete Research, 29, 1959-1967.

Waldemar, A., Klemmm, Javed, L., \& Bhatty. (2002). Fixation of heavy metals as Oxyanion-Substituted Ettringites. Portland cement Association.

Table 1. Percentage Chemical composition of HAC

\begin{tabular}{cccccccccccc}
\hline $\mathrm{CaO}$ & $\mathrm{Al}_{2} \mathrm{O}_{3}$ & $\mathrm{SiO}_{2}$ & $\mathrm{Fe}_{2} \mathrm{O}_{3}$ & $\mathrm{FeO}$ & $\mathrm{TiO}_{2}$ & $\mathrm{MgO}$ & $\mathrm{Na}_{2} \mathrm{O}$ & $\mathrm{Mn}_{2} \mathrm{O}_{3}$ & $\mathrm{P}_{2} \mathrm{O}_{5}$ & $\mathrm{SO}_{3}$ & $\mathrm{Traces}$ \\
\hline 38.5 & 39.0 & 4.5 & 10.0 & 4.0 & 2.5 & 0.4 & 0.1 & 0.1 & 0.2 & 0.15 & 0.35 \\
\hline
\end{tabular}

Table 2. Weight Percent of Phases (28 ${ }^{\text {th }}$ day)

\begin{tabular}{lccccccc}
\hline & $\mathbf{2 \theta}$ & CONTROL & CHROMIUM & LEAD & CADMIUM & ZINC & MAGNESIUM \\
\hline $\mathbf{C A H}_{\mathbf{1 0}}$ & $20^{\circ}$ & 14.75 & 10.23 & 14.75 & 11.76 & 14.25 & 12.46 \\
\hline $\mathbf{C}_{\mathbf{2}} \mathbf{A H}_{\mathbf{8}}$ & $18^{\circ}$ & 8.74 & 11.93 & 4.63 & 13.66 & 9.24 & 10.65 \\
\hline $\mathbf{A H}$ & $31^{\circ}$ & 55.14 & 55.14 & 55.14 & 55.14 & 55.14 & 55.14 \\
\hline $\mathbf{C}_{\mathbf{3}} \mathbf{A H}_{\mathbf{6}}$ & $44^{\circ}$ & 21.37 & 22.70 & 25.48 & 19.44 & 21.37 & 21.75 \\
\hline
\end{tabular}




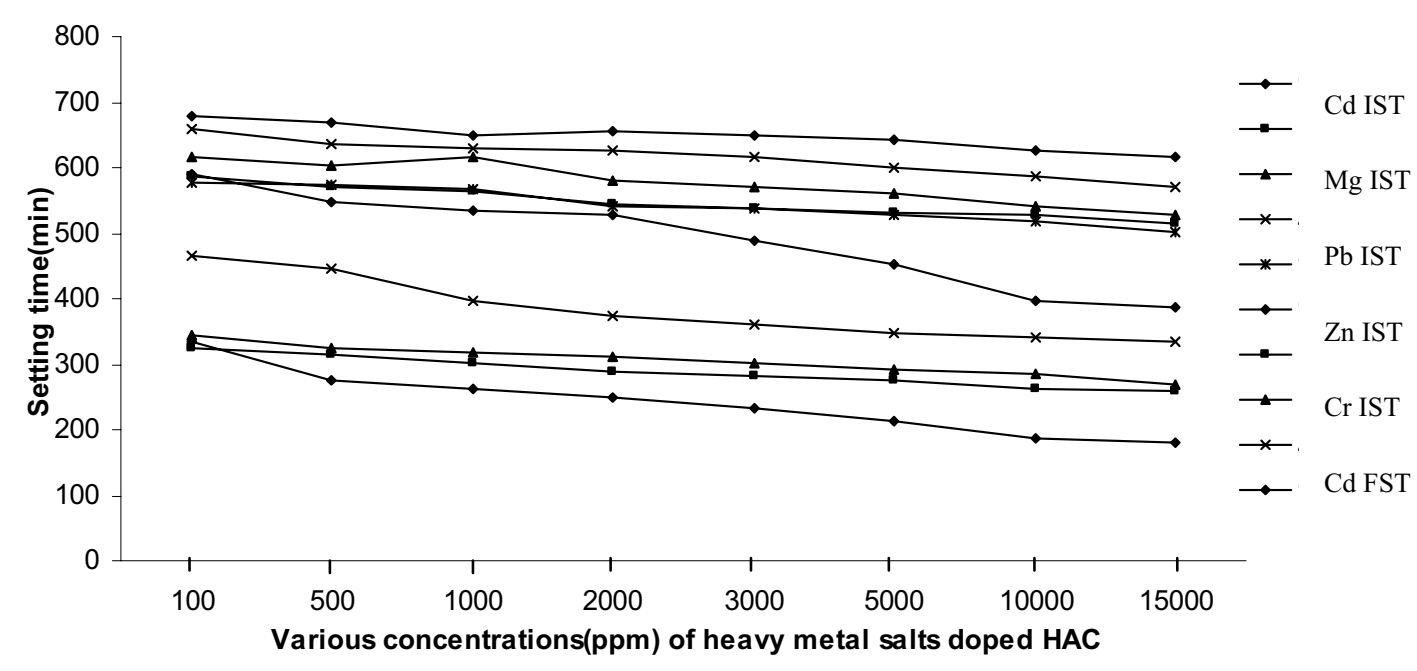

Figure 1. Setting time (IST and FST) of different metal salts doped HAC

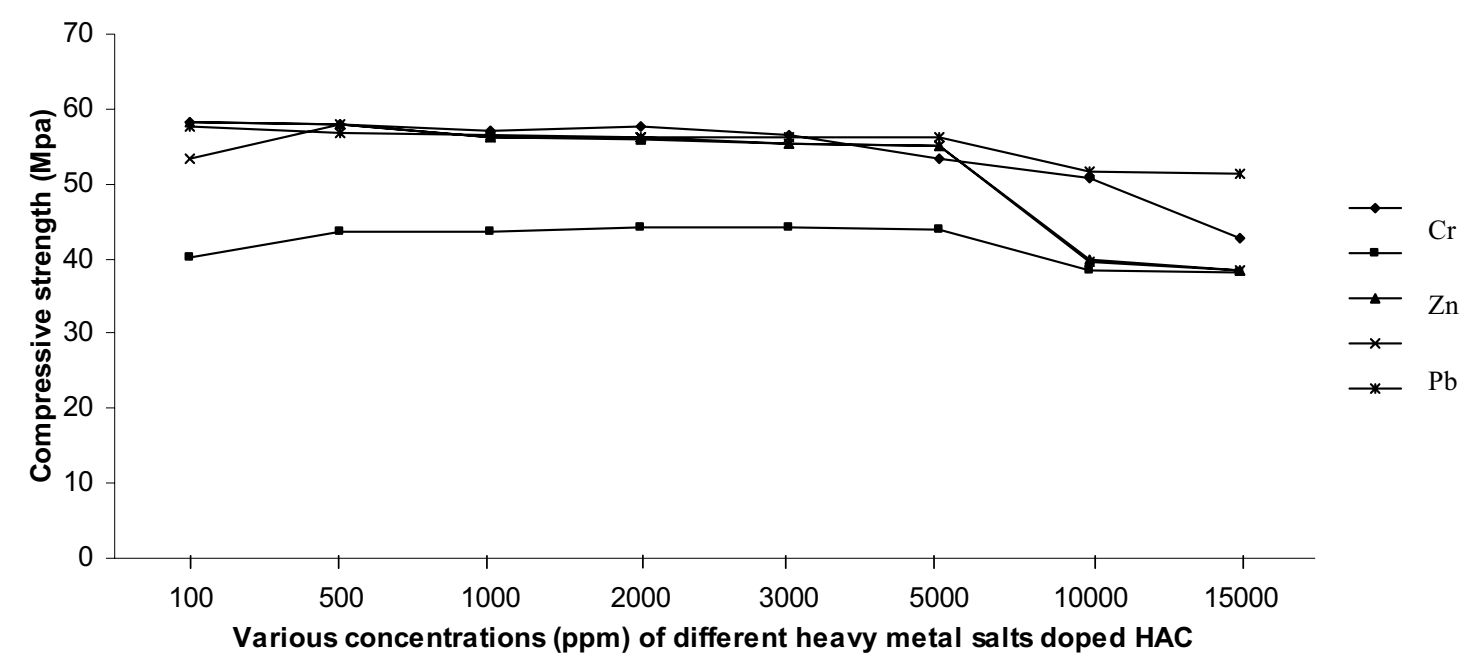

Figure 2. Compressive strength of heavy metal salts doped HAC at $28^{\text {th }}$ day 


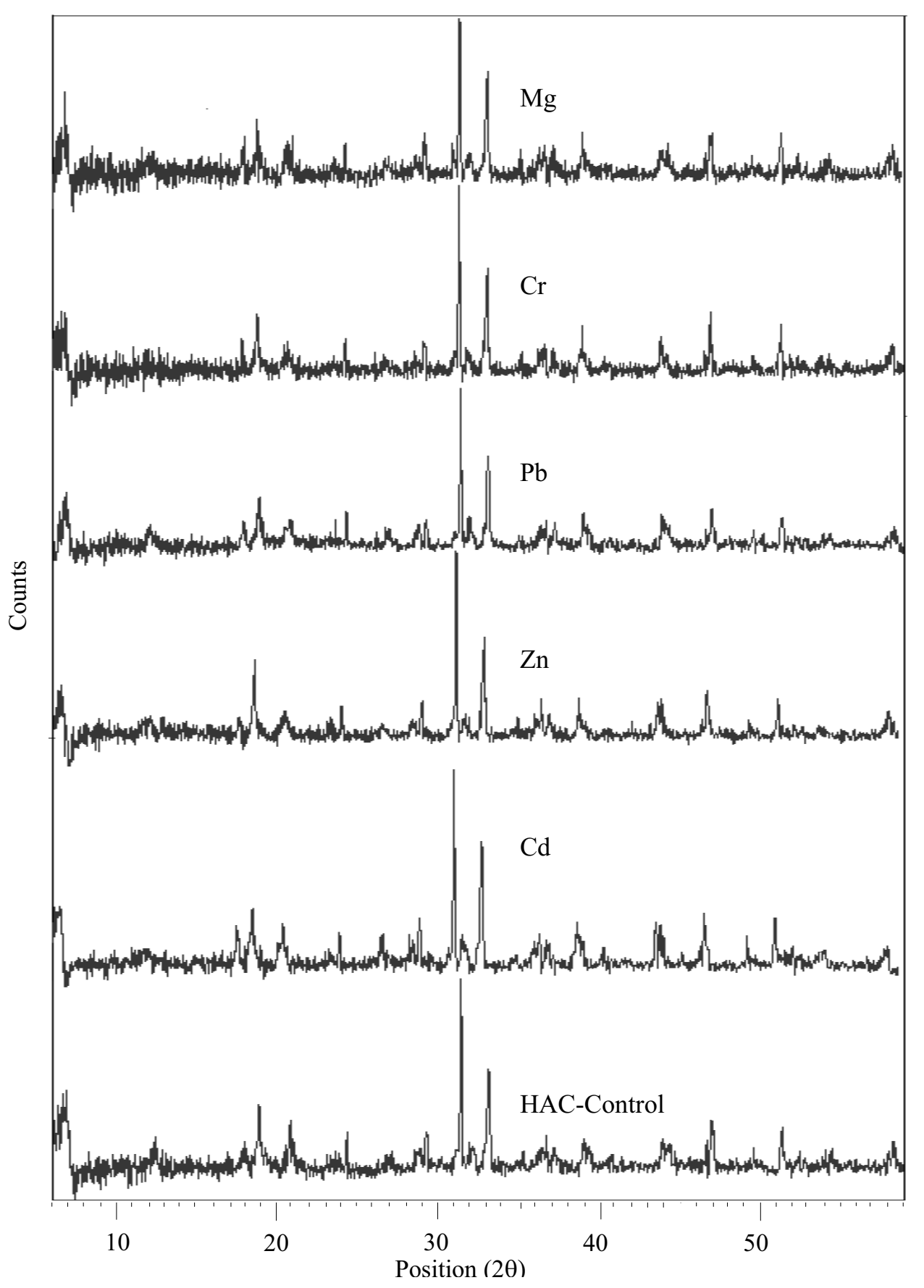

Figure 3. XRD pattern of heavy metal salts doped HAC hydrated at $28^{\text {th }}$ day 